\title{
El trauma de tórax de Alejandro Magno, una apreciación neumológica
}

\author{
José Luis Sandoval-Gutiérrez
}

Servicio de Neumología, Instituto Nacional de Enfermedades Respiratorias Ismael Cosío Villegas, Ciudad de México, México

Delgado-García, et al. ${ }^{1}$ presentan una disertación amplia, con revisión histórica profunda, de la lesión torácica que sufrió Alejandro Magno por el disparo de una saeta de dos codos de largo $(88 \mathrm{~cm})$ en la batalla contra los malios, donde a través de diversas narraciones se ha considerado que sufrió un neumotórax y que debido a la gravedad de la lesión sus médicos decidieron retirar el objeto punzocortante, obteniéndose aire y sangre posextracción; el emperador perdió el estado de alerta, recuperándose posteriormente la herida y permitiéndole montar a caballo a los pocos días. Los autores finalizan con la frase «Lo sucedido después del flechazo torna inverosímil la posibilidad de un neumotórax».

Cabe señalar que la posibilidad de un neumotórax a tensión en la circunstancia y escenario de la época hacen que prácticamente el paciente hubiese fallecido, por lo que la probabilidad de un neumotórax parcelar sea lo más certero.

El entrenamiento desde la niñez de los soldados macedonios con las jornadas exhaustivas de lucha cuerpo a cuerpo, equitación, contusiones, manejo de armas etc., hacía que los soldados de dichas agrupaciones tuvieran una condición física fuera de serie; el ser herido y convivir con traumatismos eran la norma más que la excepción.

La caja torácica, por su composición y exposición, es un lugar idóneo para el contrincante como objeto de lesión. Esto se manifiesta por la necesidad imperante de chalecos de protección en diferentes deportes, como el taekwondo, la esgrima o el rodeo, y en profesiones como guardaespaldas, policías, soldados y escoltas de seguridad.

En la vida moderna nos encontramos con pacientes que tienen actividades con gran esfuerzo físico, como albañiles, campesinos, vaqueros, rancheros, etc., en cuya valoración médica nos encontramos con fracturas costales, hemotórax, empiema, cavidades pulmonares, engrosamiento pleural, neumomediastino, quistes o neumotórax retenido, que a pesar de lo característico en las imágenes radiológicas el paciente no presenta sintomatología significativa.

La dinámica del trauma torácico en el caso referido invita al análisis de haberse tratado de un hemoneumotórax retenido²; el coágulo sanguíneo provocó que el neumotórax se limitara, permitiendo la recuperación de Alejandro Magno.

Felicito a los autores por su profunda investigación médica de este gran personaje de la historia universal.

\section{Bibliografía}

1. Delgado-García G, Villarreal-Alarcón MA, Estañol-Vidal B. El neumotórax de Alejandro Magno: una apreciación crítica. Gac Med Mex. 2016;152:843-9.

2. Campos Gómez X, Vega Ávalos AG. Hemotórax. Med Leg Costa Rica. 2016;33:1409.

\section{Correspondencia:}

José Luis Sandoval-Gutiérrez

Servicio de Neumología, Instituto Nacional de 